Article

\title{
Distribution of Pseudomonas fluorescens and Aeromonas hydrophila Bacteria in a Recirculating Aquaculture System during Farming of European Grayling (Thymallus thymallus L.) Broodstock
}

\author{
Iwona Gołaś $^{1, *(1)}$, Mariusz Szmyt ${ }^{2}{ }^{\oplus}$, Jacek Potorski ${ }^{1}$, Michał Łopata ${ }^{3}$, \\ Anna Gotkowska-Płachta ${ }^{1}$ and Katarzyna Glińska-Lewczuk ${ }^{4}$ (D) \\ 1 Department of Environmental Microbiology, University of Warmia and Mazury in Olsztyn, \\ Prawocheńskiego 1, 10-957 Olsztyn, Poland; jacek.potorski@uwm.edu.pl (J.P.); aniagp@uwm.edu.pl (A.G.-P.) \\ 2 Department of Fish Biology and Pisciculture, University of Warmia and Mazury in Olsztyn, \\ Oczapowskiego 5, 10-957 Olsztyn, Poland; mariusz.szmyt@uwm.edu.pl \\ 3 Department of Water Protection Engineering, University of Warmia and Mazury in Olsztyn, \\ Prawocheńskiego 1, 10-957 Olsztyn; michal.lopata@uwm.edu.pl \\ 4 Department of Water Resources, Climatology, and Environmental Management, \\ University of Warmia and Mazury in Olsztyn, Plac Lodzki 2, 10-759 Olsztyn, Poland; kaga@uwm.edu.pl \\ * Correspondence: iwonag@uwm.edu.pl; Tel.: +48-89-52345 57
}

Received: 28 January 2019; Accepted: 18 February 2019; Published: 21 February 2019

check for updates

\begin{abstract}
Pseudomonas fluorescens and Aeromonas hydrophila bacteria are opportunistic pathogens that occur naturally in the aquatic environment and in the gut flora of healthy fish. Both species can pose a serious threat for fish that are highly sensitive to water pollution. The aim of this study was to determine the extent to which the amount of administered fish feed and fish biomass affect the distribution and abundance of $P$ s. fluorescens and $A$. hydrophila bacteria in a recirculating aquaculture system (RAS) during farming of European grayling (Thymallus thymallus L.) broodstock. A total of 68 water samples from the inflow, two rearing tanks and the outflow as well as 17 feed samples were collected and analyzed separately. Bacterial populations were analyzed by the culture-dependent method and a molecular method (fluorescence in situ hybridization, FISH) to detect culturable strains and viable but non-culturable strains, respectively. Fish biomass, feed and 16 water quality parameters (temperature, $\mathrm{pH}$, concentration of dissolved oxygen, oxygen saturation, five-day biochemical oxygen demand $\left(\mathrm{BOD}_{5}\right)$, total phosphorus, total organic phosphorus and nitrogen, orthophosphates, total nitrogen, nitrite and nitrate nitrogen, ammonia nitrogen, ammonium nitrogen, total suspended solids, and total organic carbon) were the explanatory factors. Statistically significant differences (RM-ANOVA, $\mathrm{p} \leq 0.05$ ) were stated in bacterial abundance in samples from the inflow, rearing tanks and the outflow. Water samples from the RAS were abundantly colonized by non-culturable Ps. fluorescens and A. hydrophila bacteria. Feed was not a source of bacteria, but a redundancy analysis (RDA) revealed that the amount of feed, fish biomass, $\mathrm{BOD}_{5}$, and total suspended solids and total organic carbon were positively correlated in both Ps. fluorescens and A. hydrophila. These parameters also influenced the distribution of both potentially pathogenic bacterial populations and contributed to the bacterial contamination of water in the RAS. Our results are particularly valuable for aquacultures that help to replenish wild stocks and rebuild populations of threatened species in natural aquatic environments.
\end{abstract}

Keywords: RAS; European grayling; fish rearing; bacteria; Ps. fluorescens; A. hydrophila 


\section{Introduction}

In most commercial RAS, the safety of the production process and the well-being of fish and other aquatic organisms is controlled based on the physicochemical parameters of water (temperature, $\mathrm{pH}$, and oxygen and ammonia content) and the growth performance of fish (body weight gain, relative growth rate, relative biomass, and changes in total body length). The significance of microbiological analyses of the aquatic environment, aquatic organisms, and feeds is often under-appreciated. In some cases, microbiological assays are not performed even when the first worrying physical or behavioral symptoms are observed in aquatic organisms. This negligence often stems from the lack of awareness that aquatic microbiota can have a greater influence on the health and growth of fish than feed microbiota [1-3]. Water microbiota can decrease production results or even cause massive production losses. From the environmental and epidemiological point of view, the increase in the abundance and activity of heterotrophic and potentially pathogenic microbiota in aquatic environments can pose a serious threat for human and animal health [4-6].

Recirculating aquaculture systems (RAS) with intensively farmed fish are specific ecosystems where the continuous recycling of water contributes to microbial heterotrophy. The physicochemical parameters of water (e.g., temperature, $\mathrm{pH}$, concentration of dissolved oxygen, and $\mathrm{NH}_{4}-\mathrm{N}, \mathrm{NO}_{2}-\mathrm{N}$ ), the type and quantity of the administered feed, stock size, and the growth stages of aquatic organisms induce rapid periodic changes in the structure of dominant physiological groups, genera and species of heterotrophic bacteria [7-13]. These processes should be monitored to evaluate the quality of aquatic environments [14]. The above changes cannot be determined based on chemical assays alone. Microorganisms are among the most sensitive [15]. In intensive fish farming, the above applies particularly to changes in the populations of Pseudomonas fluorescens and Aeromonas hydrophila which constitute natural microbiota in both the aquatic environment and fish, but are also one of the most frequently diagnosed epizootic risk factors affecting fish around the world $[6,13,16,17]$. The above bacterial species belong to the class Gammaproteobacteria. They are ubiquitous in aquatic environments, and they are capable of decomposing various organic compounds due to a broad range of enzymatic activities [13,14,18,19]. Pathogenic strains of Ps. fluorescens and A. hydrophila have hemolytic and proteolytic properties, and they rapidly acquire resistance against popular antibiotics [4-6,16,20-23]. However, the activity and abundance of these bacteria in aquatic environments depend on physicochemical parameters (water temperature, $\mathrm{pH}$, content of mineral substances, and organic compounds) and biological factors (predation and interspecific competition).

Ps. fluorescens and A. hydrophila can be easily cultured on selective media where they form characteristic colorful colonies [24,25]. These bacteria can also be identified with the use of molecular techniques such as fluorescent in situ hybridization (FISH). In the FISH method, specific oligonucleotide probes are used to identify bacterial species under an epifluorescence microscope [26]. This method supports rapid detection (6-8 h) and identification of viable but non-culturable (VBNC) Ps. fluorescens and A. hydrophila bacteria which lose the ability to proliferate on standard growth media but remain viable in the environment [19,27]. Culturable and non-culturable potentially pathogenic Ps. fluorescens or A. hydrophila can spread from aquacultures and induce changes in the total populations of bacteria in aquatic ecosystems. For this reason, conventional (culture-dependent) and molecular (culture-independent, such as FISH) methods can be combined to detect the bacteria that colonize those ecosystems, and observe changes in the quantitative and qualitative composition of microbiota in aquatic ecosystems [28-30].

The complete life cycle or selected growth stages (e.g., until the achievement of commercial value) of aquatic organisms can be monitored in experimental RAS. Experimental farms are often established to strengthen or reinstate aquatic species whose natural populations have declined due to anthropogenic pressure. In RAS, farming conditions can be optimized and controlled to produce organisms capable of adapting to degraded aquatic environments. Such experiments are often performed on the European grayling (Thymallus thymallus L.) which is highly popular among anglers and is the most economically valuable salmonid species [31]. However, this rheophilic species has high oxygen requirements $\left(7-10 \mathrm{mg} \mathrm{O} \mathrm{O}_{2} \cdot \mathrm{L}^{-1}\right)$, and it is highly sensitive to water contamination [31]. 
For this reason, the European grayling is regarded as a valuable bioindicator of anthropogenic pollution. Anthropogenic pressure [32-34], including strong pressure from recreational fishing [35], progressing eutrophication and pollution of rivers [36-38], have led to a dramatic decline in European grayling populations throughout Europe. These observations are particularly important for European graylings aged 3 to 5 years, which are characterized by the highest reproductive potential, as well as individuals older than 5 years which account for up to $4 \%$ of the grayling population in many European regions [39,40]. For these reasons, the European grayling was classified as a conservation dependent (CD) species on the 2009 Red List of Fish and Lamprey Species [41]. This implies that active and effective protection is required to preserve the natural populations of the European grayling.

In order to produce good health fry for stocking the European grayling (Thymallus thymallus L.) broodstock (between 3 to 5 years old), was cultivated in RAS at the Department of Fish Biology and Pisciculture of the Faculty of Environmental Sciences at the University of Warmia and Mazury in Olsztyn (Poland) [42,43]. During experimental farming in RAS, the microbiological and physicochemical parameters of water, fish growth parameters (increase in fish biomass) and the amounts of feed were monitored in characteristic sites. The studied microorganisms were Ps. fluorescens and A. hydrophila which: (i) constitute the natural microbiota of water and fish [4,5,10-12], (ii) can be potentially pathogenic for fish and humans [6,21,22,44], (iii) are characterized by high levels of cross-resistance to popular antibiotics $[4,5]$ and (iv) are detected in growing concentrations in water evacuated from various aquaculture systems in Poland $[4,10-12,44]$ and in the world $[13,14,45]$.

Very little is known about the factors that affect the distribution of potentially pathogenic Ps. fluorescens and A. hydrophila bacteria during intensive fish rearing in RAS. This study tested the hypothesis postulating that the amount of fish feed and fish biomass influence the distribution and abundance of Ps. fluorescens and A. hydrophila in a recirculating aquaculture system (RAS) during farming of European grayling (Thymallus thymallus L.) broodstock.

Standardised culture-dependent and culture-independent methods (FISH) were used to determine changes in the populations of Ps. fluorescens and A. hydrophila during intensive fish rearing in RAS. Bacterial contamination is a very important consideration in freshwater ecology because potentially pathogenic Ps. fluorescens and A. hydrophila bacteria colonizing water and intensively farmed fish can spread from aquacultures and contaminate the natural environment with non-specific microbiota.

\section{Materials and Methods}

\subsection{Study Area and Sampling Sites}

European grayling (Thymallus thymallus L.) broodstock was experimentally bred in a recirculating aquaculture system in the Department of Fish Biology and Pisciculture of the Faculty of Environmental Sciences at the University of Warmia and Mazury in Olsztyn (Poland). Total bacterial counts, the counts of Ps. fluorescens and A. hydrophila bacteria, and the physicochemical parameters of water, including temperature, $\mathrm{pH}$, concentration of dissolved oxygen (DO), oxygen saturation (OS), 5-day biochemical oxygen demand (BOD 5 ), orthophosphates $\left(\mathrm{PO}_{4}-\mathrm{P}\right)$, total phosphorus (TP), $\mathrm{NH}_{4}-\mathrm{N}, \mathrm{NH}_{3}-\mathrm{N}_{1} \mathrm{NO}_{2}-\mathrm{N}, \mathrm{NO}_{3}-\mathrm{N}$, total suspended solids (TSS), total organic carbon (TOC), total nitrogen (TN), total organic nitrogen (TON), and total organic phosphorus (TOP) were monitored over a period of 17 months between December 2013 and April 2015.

European grayling (Thymallus thymallus L.) was experimentally bred in nine fish rearing tanks (Figure 1), including six tanks with a volume of $0.32 \mathrm{~m}^{3}$ each and three tanks with a volume of $0.98 \mathrm{~m}^{3}$ each. Tank water was filtered by a purification system composed of a microstrainer $(60 \mu \mathrm{m}$ pore size, processing capacity of $20 \mathrm{~m}^{3} \cdot \mathrm{h}^{-1}$ ), a trickling filter (with a volume of $1.5 \mathrm{~m}^{3}$ and an active surface area of $1100 \mathrm{~m}^{2}$ ) and a UV lamp $(105 \mathrm{~W})$. Water was cooled to the optimal temperature in a glycol chiller. Daily water loss of around $3 \%\left(200 \mathrm{~L}^{- \text {day }^{-1}}\right)$ was supplemented. During 17 months of the experiment, total fish biomass increased from $9.27 \mathrm{~kg}$ to $54.49 \mathrm{~kg}$. The fish were fed commercial feed with $45-55 \%$ protein content and $15-20 \%$ fat content, depending on the age, growth stage and body weight of fish. The feed ration was adjusted to feed intake. A total of $87.44 \mathrm{~kg}$ of feed was used during the experiment, and $5.5 \pm 1.3 \mathrm{~kg} \cdot \mathrm{m}^{-1}$ of feed 
was administered monthly on average, subject to the nutrient requirements and the growth stages of fish. The average total monthly increase in fish biomass was $2.7 \pm 0.8 \mathrm{~kg} \cdot \mathrm{m}^{-1}$.

The experimental materials were water samples collected from four sites and fish feed. Water was sampled from the inflow, two rearing tanks and the outflow from rearing tanks (Figure 1). The triplicate subsamples were combined in equal proportions, and the pooled sample was subjected to microbiological and physicochemical analyses. Pooled water samples were collected from each site at monthly intervals. A total of 17, 17, 17, and 17 water samples were acquired from: the inflow, two rearing tanks (no. 1 and no. 2) and the outflow, respectively. Feed samples, fish biomass and the amount of feed were monitored. A total of 68 water samples and 17 feed samples were collected and analyzed separately. All water samples were placed in sterile bottles at $4{ }^{\circ} \mathrm{C}$, transported to a laboratory and assayed within $12 \mathrm{~h}$ of collection. Fish feed was sampled at the experimental site and placed in sterile measuring vessels.

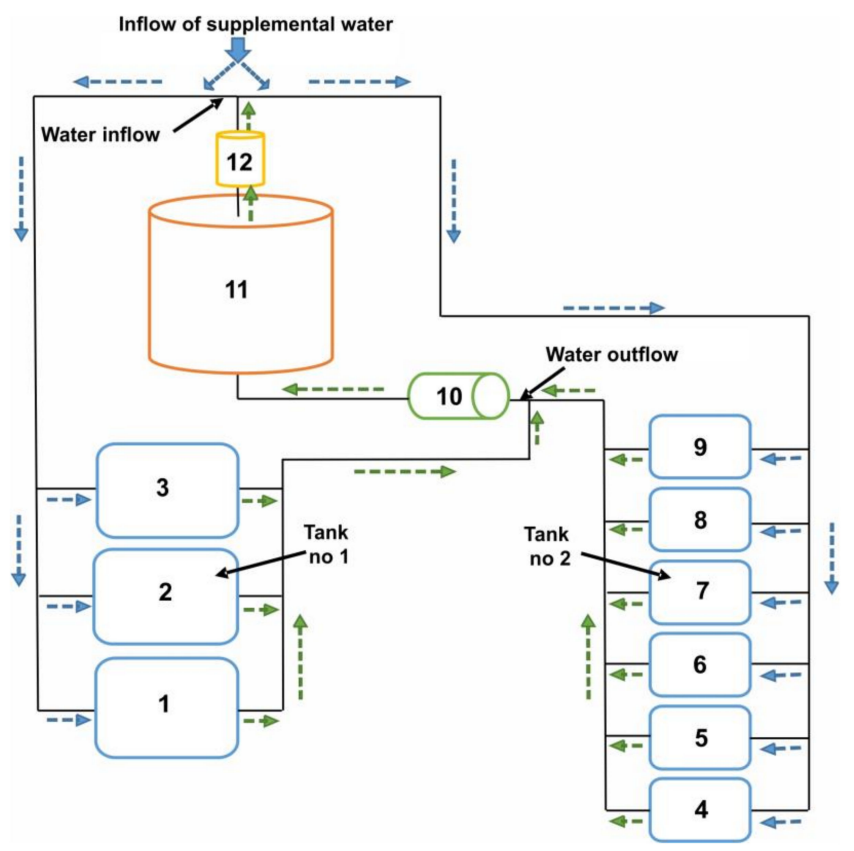

Figure 1. Diagram of the recirculating aquaculture system (RAS) and water sampling sites. Denotations: 1, 2, 3-fish rearing tanks $\left(0.98 \mathrm{~m}^{3}\right) ; 4,5,6,7,8$, 9-fish rearing tanks $\left(0.32 \mathrm{~m}^{3}\right)$; 10 -microstrainer; 11-trickling filter; 12-UV lamp.

\subsection{Microbiological Analysis}

Microbiological analyses relied on culture-dependent and culture-independent methods. The culture-dependent method involved plate counts, isolation and biochemical identification to detect culturable Ps. fluorescens and A. hydrophila strains. Culture-independent methods relied on molecular techniques, DAPI staining (with 4',6-diamidino-2-phenylindole dihydrochloride) (Sigma-Aldrich, St. Louis, MO, USA) and fluorescence in situ hybridization (FISH) to determine the counts of visible but non-culturable Ps. fluorescens and A. hydrophila bacteria. The FISH method based on targeted with 16rRNA oligonucleotide probes, usually of the length of 15-30 nucleotides, allows to identify large phylogenetic groups, individual species of bacteria as well as to demonstrate the structure of microbial communities and their dynamics in the environments.

2.2.1. Determination of Ps. fluorescens and A. hydrophila Counts by the Culture-Dependent Method in Samples of RAS Water and Fish Feed

Aliquots of $1 \mathrm{~mL}$ of pooled samples of water collected from the inflow, two rearing tanks and the outflow were diluted in $9 \mathrm{~mL}$ of sterile phosphate-buffered saline (PBS). Feed samples of $10 \mathrm{~g}$ each were homogenized with $90 \mathrm{~mL}$ of PBS. Serial dilutions with PBS were prepared to reduce bacterial 
density. Subsequently, $0.1 \mathrm{~mL}$ of every homogenized solution was subjected to microbiological analysis. In quantitative microbiological analyses, water and feed samples were cultured on selective media, and the counts of Ps. fluorescens and A. hydrophila bacteria were determined by the pour plate method. Ps. fluorescens bacteria were cultured on King's B medium for $72 \mathrm{~h}$ at $28{ }^{\circ} \mathrm{C}$ according to Standard Methods for the Examination of Water and Wastewater (APHA) [46]. Ps. fluorescens colonies cultured on King's B medium were analyzed under Wood's UV lamp, and the number of fluorescein-producing colonies was counted. A. hydrophila were enumerated, incubated at $30^{\circ} \mathrm{C}$ for $24 \mathrm{~h}$, and isolated by plating on the Aeromonas Medium Base (Ryan). A. hydrophila colonies were counted based on the number of opaque green colonies with a dark centre formed in a color reaction with the Aeromonas Medium Base (Ryan). The number of colonies which were cultured on selective media and identified based on their morphology (cell shape, Gram stain reaction, motility in microscopic preparations) and enzymatic activity (ability to produce catalase and cytochrome oxidase, capacity for oxidative degradation, and fermentation of glucose on the Hugh-Leifson medium) was taken into account in the determination of Ps. fluorescens and A. hydrophila counts. Ps. fluorescens and A. hydrophila bacteria were further identified with the use of the API 20NE biochemical test strips (BioMérieux ${ }^{\circledR}$, France) for Gram negative non-Enterobacteriaceae. The analyses were performed according to the Standard Methods for the Examination of Water and Wastewater [46]. All determinations were performed in three replicates in the same sample of water or fish feed. Plate counts were expressed as colony-forming units (CFU) per $1 \mathrm{~mL}$ of water or per $1 \mathrm{~g}$ of fish feed.

2.2.2. Determination of Total Bacterial Counts in RAS Water and Fish Feed Samples by DAPI Staining and in Situ Hybridization FISH

The protocols for the fixation, hybridization and microscopic quantification of bacterial communities by the FISH method and DAPI staining were similar to those described in a previous study $[28,47]$. After preliminary analyses, selected hybridization conditions were modified to optimize the results. This approach increased the efficiency of FISH analysis to $75-90 \%$ of total cell counts.

Total bacterial counts were determined in $1 \mathrm{~mL}$ samples of RAS water (collected from different sites with different suspension concentrations) and $1 \mathrm{~g}$ of fish feed. Triplicate subsamples of water collected from the inflow, two rearing tanks and the outflow and fish feed were fixed with neutralized formaldehyde ( $\mathrm{pH} 7.4$, final concentration of $4 \%$ ) and stained with $4^{\prime}, 6^{\prime}$-diamidino-2-phenyloindole (DAPI, showing affinity for cellular DNA) (Sigma-Aldrich, St. Louis, MO, USA) with a final concentration of $0.01 \mathrm{ng} \cdot \mathrm{mL}^{-1}$, for $15 \mathrm{~min}$ in the dark [48]. Fixed samples were gently passed through black Nuclepore filters with $0.2 \mu \mathrm{m}$ pore size (GTTP, Millipore). Filters were rinsed with $10 \mathrm{~mL}$ of ultrapure water (MQ Millipore) to remove excess paraformaldehyde and dried for several minutes at room temperature. Bacteria were counted under an Olympus epifluorescence microscope. More than 1000 bacterial cells were counted in 20 fields of view.

The number of $P_{s}$. fluorescens and A. hydrophila bacteria was determined in 10-20 mL samples of water collected from the inflow, two rearing tanks and the outflow and in $1 \mathrm{~g}$ of fish feed. Triplicate subsamples were fixed with the same method that was used in the determination of total bacterial counts. Fixed samples were passed through white polycarbonate filters $(0.2 \mu \mathrm{m}$ pore size, $47 \mathrm{~mm}$ in diameter) (GTTP, Millipore) under low negative pressure with the use of base filters $(0.45 \mu \mathrm{m}$ pore size, Sartorius) to distribute cells evenly on filters. The samples fixed on filters were subjected to the FISH procedure with the use of specific oligonucleotide probes. Ps. fluorescens was identified with the Pseudo120 probe (Thermo Fisher Scientific GmbH, Ulm, Baden-Württemberg, Germany) [19] A. hydrophila-with the KO 229 probe (Thermo Fisher Scientific GmbH, Ulm, Baden-Württemberg, Germany) [27]. The GAM42a competitor probe (Thermo Fisher Scientific GmbH, Ulm, Baden-Württemberg, Germany) [49] and the probe specific for domain Bacteria (EUB338) (Thermo Fisher Scientific GmbH, Ulm, Baden-Württemberg, Germany) were applied to identify all bacterial species [50]. All samples were simultaneously screened with the NON338 probe (Thermo Fisher Scientific GmbH, Ulm, Baden-Württemberg, Germany) [51] to control autofluorescence and the number of non-specifically stained cells which did not exceed $5 \%$ on average [52]. The probe 
sequences, hybridization conditions and references are given in Table 1 . The composition of bacterial communities was investigated by fluorescent in situ hybridization (FISH) with the use of Cy3-labeled oligonucleotide probes (Thermo Fisher Scientific GmbH, Ulm, Baden-Württemberg, Germany) in accordance with the hybridization procedure for aquatic microorganisms proposed by Pernthaler et al. [47]. After the FISH procedure, the specimens were viewed under a fluorescence microscope (Olympus BX61) equipped with a $\times 100$ oil immersion lens (Olympus Poland, Warsaw, Masovia, Poland), UV lamp (Olympus Poland, Warsaw, Masovia, Poland), DAPI and CY3 filters (Olympus Poland, Warsaw, Masovia, Poland) and CCD camera (Olympus) (Olympus Poland, Warsaw, Masovia, Poland). Images were analyzed in the Cell $\mathrm{F}$ application (Olympus). More than 100 hybridized bacterial cells (FISH) and 1000 to 10,000 DAPI-stained bacterial cells were identified per every evaluated sample. Mean values, range and standard deviation were calculated from 20 random fields of view in every filter section and expressed in terms of $1 \mathrm{~mL}$ of water and $1 \mathrm{~g}$ of fish feed. Pseudo120 and KO 229 probe-specific cell counts (of Ps. fluorescens and A. hydrophila, respectively) were expressed as the number and percentage of cells visualized by DAPI staining.

Table 1. Oligonucleotide probes used for bacteria determination by hybridization in situ (FISH) method during farming of European grayling (Thymallus thymallus L.) broodstock in RAS.

\begin{tabular}{cccccc}
\hline Probe & Target Species & $\begin{array}{c}\text { Target }^{\mathbf{1}} \text { Site } \\
\text { (rRNA Positions) }\end{array}$ & $\begin{array}{c}\text { \% FA }^{\mathbf{2}} \\
\text { in situ }\end{array}$ & TF $^{\mathbf{3}}$ & Reference \\
\hline EUB338 & $\begin{array}{c}\text { Bacteria } \\
\text { Control probe }\end{array}$ & $16 S(338-355)$ & 35 & 48 & {$[50]$} \\
NON338 & complementary to EUB338 & $16 S(338-355)$ & 35 & 48 & {$[51]$} \\
GAM42a & Gammaproteobacteria & $23 S(1024-1043)$ & 35 & 47 & {$[49]$} \\
GAM42a' & Gamma competitor & $23 S(1024-1043)$ & 35 & 47 & {$[49]$} \\
Pseudo120 & Ps. fluorescens & 16 S (120-142) & 30 & 57 & {$[19]$} \\
KO 229 & A. hydrophila & $16 S(454-474)$ & 30 & 49 & {$[27]$} \\
\hline
\end{tabular}

\subsection{Physicochemical Parameters of RAS Water}

Selected physicochemical parameters of RAS water were determined during the collection of microbiological samples. Microbiological and physicochemical assays were carried out in the same water samples from inflow, two rearing tanks and the outflow. Temperature $\left({ }^{\circ} \mathrm{C}\right)$, dissolved oxygen concentration ( $\mathrm{DO} \mathrm{mg} \mathrm{O} \mathrm{O}_{2} \cdot \mathrm{L}^{-1}$ ), oxygen saturation (OS) and $\mathrm{pH}$ were analyzed in situ with the WTW Multiline P4 multi-parameter sensor (Xylem Analytics Germany Sales GmbH \& Co. KG WTW, Weilheim, Bavaria, Germany) and YSI PRO-ODO optical oxygen sensor (YSI Incorporated, Yellow Springs, $\mathrm{OH}, \mathrm{USA}$ ) to the nearest $\pm 0.1{ }^{\circ} \mathrm{C}, \pm 0.01 \mathrm{mg} \mathrm{O}_{2} \cdot \mathrm{L}^{-1}, \pm 0.1 \% \mathrm{O}_{2}$ and $\pm 0.01 \mathrm{pH}$, respectively. The values of five-day biochemical oxygen demand $\left(\mathrm{BOD}_{5} \mathrm{mg} \mathrm{O}_{5} \cdot \mathrm{L}^{-1}\right)$ and the concentrations of orthophosphate $\left(\mathrm{PO}_{4}-\mathrm{P} \mathrm{mg} \mathrm{P} \cdot \mathrm{L}^{-1}\right)$, total phosphorus (TP mg P. $\left.\mathrm{L}^{-1}\right)$, ammonium nitrogen $\left(\mathrm{NH}_{4}-\mathrm{N}\right.$ $\left.\mathrm{mg} \mathrm{N} \cdot \mathrm{L}^{-1}\right)$ nitrogen-ammonia $\left(\mathrm{NH}_{3}-\mathrm{N} \mathrm{mg} \cdot \mathrm{L}^{-1}\right)$, nitrite nitrogen $\left(\mathrm{NO}_{2}-\mathrm{N} \mathrm{mg} \mathrm{N} \cdot \mathrm{L}^{-1}\right)$, nitrate nitrogen $\left(\mathrm{NO}_{3}-\mathrm{N} \mathrm{mg} \mathrm{N} \cdot \mathrm{L}^{-1}\right)$ and total suspended solids (TSS $\mathrm{mg} \cdot \mathrm{L}^{-1}$ ) were determined according to the Standard Methods [46]. All spectrophotometric analyses were performed with the Merck SQ118 photometer (Merck KGaA, Darmstadt, Hesse, Germany). Total organic carbon (TOC $\mathrm{mg} \mathrm{C} \cdot \mathrm{L}^{-1}$ ) was determined with the HACH IL 550 TOC-TN analyzer (Hach Lange, Dusseldorf, North-Rhine Westphalia, Germany). Total nitrogen (TN mg N. $\mathrm{L}^{-1}$ ) was determined as nitrogen oxides after mineralization $\left(850^{\circ} \mathrm{C}\right)$ in a chemiluminescence detector (HACH IL 550 TOC-TN analyzer). Total organic phosphorus (TOP mg P. $\mathrm{L}^{-1}$ ) and total organic nitrogen (TON mg N. $\mathrm{L}^{-1}$ ) were determined as the difference between total phosphorus and nitrogen and mineral phosphorus and nitrogen, respectively.

\subsection{Statistical Analysis}

Statistical analyses were carried out using the XLSTAT ver. 2018.3 software (2018.3 version, Addinsoft, New York, NY, USA) provided by Microsoft Excel ${ }^{\circledR}$ by Addinsoft. To assess the influence of recirculated water on the bacteria counts and chemical composition of water throughout the 
experiment, one-way Repeated Measure ANOVA (RM-ANOVA) was carried out with "site" (three levels: inflow, tank, outflow) regarded as a fixed factor, with 17 repeated measurements over the period of 17 months. Homogeneity of variance was tested using Levene's F-test. For RM-ANOVA Mauchly's test was used to check the assumption of sphericity. When the assumption of sphericity was violated for the within-subject effect, the degrees of freedom and thereby the F-value were corrected using the Greenhouse-Geisser correction. Significant differences among means were identified using a Tukey's multiple comparison test (HSD). Statistical significance was set at 0.05 [54].

The differences in the abundance of the studied bacterial populations determined by culture-dependent and culture-independent methods, and the relationships between bacterial populations and environmental variables (fish biomass, amount of feed, and the physicochemical parameters of water) were determined by linear redundancy analysis (RDA). This method was applied because a preliminary detrended correspondence analysis (DCA) had demonstrated that the data were characterized by a linear response (gradient length $<2.0 \mathrm{SD}$ units) to the analyzed environmental parameters [55]. In our analysis, the calculated gradient length was $0.4 \mathrm{SD}$ units; therefore, redundancy analysis (RDA) was applied to determine the relationships between bacterial counts and fish biomass, amount of feed and water quality parameters. Full sets of environmental variables were screened by automatic forward selection in the Monte Carlo randomization test (999 permutations) [56], and only variables that were significantly $(\mathrm{p} \leq 0.05)$ related to assemblage structure were retained to further analysis. In the final RDA model, the appropriate subset of explaining variables were selected by the Bonferroni correction to reduce the factors that were not significant for the model. Following the Bonferroni correction, the collinearity between explanatory variables was reduced by eliminating selected variables with a variation inflation factor (VIF) greater than 10 [55]. For this reason twelve physicochemical variables (temperature, $\mathrm{pH}, \mathrm{DO}, \mathrm{OS}, \mathrm{PO}_{4}-\mathrm{P}, \mathrm{TP}, \mathrm{NH}_{4}-\mathrm{N}, \mathrm{NH}_{3}-\mathrm{N}, \mathrm{NO}_{3}-\mathrm{N}_{2} \mathrm{NO}_{2}-\mathrm{N}$, TON, TN) were eliminated as redundant in the final RDA model. The multivariate analyses were carried out in CANOCO ver. 5.0 (Microcomputer Power, Ithaca, NY, USA) [57].

\section{Results and Discussion}

\subsection{Ps. fluorescens and A. hydrophila Counts in Samples of Water and Fish Feed}

The counts of Ps. fluorescens and A. hydrophila determined by culture-dependent and culture-independent methods were highly similar in water samples collected from both water rearing tanks (no. 1 and no. 2). In water samples from rearing tanks no. 1 and no. 2, Ps. fluorescens counts were determined at $140 \pm 60$ and $170 \pm 75 \mathrm{cfu} \cdot \mathrm{mL}^{-1}$ by the culture-dependent method, respectively, and at $3.2 \times 10^{6} \pm 1.3 \times 10^{6}$ and $2.9 \times 10^{6} \pm 1.7 \times 10^{6}$ cells. $\mathrm{mL}^{-1}$ by the culture-independent method, respectively. A. hydrophila counts in water samples from tank no.1 and 2 were determined at $240 \pm 75$ and $220 \pm 85 \mathrm{cfu} \cdot \mathrm{mL}^{-1}$, respectively, by the culture-dependent method, and at $4.7 \times 10^{6} \pm 1.6 \times 10^{6}$ and $4.3 \times 10^{6} \pm 1.9 \times 10^{6}$ cells $\mathrm{mL}^{-1}$, respectively, by the culture-independent method. No significant differences $(\mathrm{p} \leq 0.05)$ between the counts of Ps. fluorescens and A. hydrophila bacteria determined by both methods were found in water samples collected from tank no. 1 and 2 (t-test, $\mathrm{p}>0.05$ ). For this reason, bacterial counts in two fish tanks were pooled presented as the average values for both tanks.

The mean values and the range of Ps. fluorescens and A. hydrophila counts determined by culture-dependent and culture-independent methods are presented in Table 2 and Figure 2. Bacterial counts were determined within a range spanning several orders of magnitude $\left(10^{1}-10^{8}\right)$, depending on species, the applied analytical method and sampling site (inflow, tank and outflow). The RM-ANOVA revealed significant differences in Ps. fluorescens (Tukey test, $\mathrm{F}=62.32, \mathrm{p}=0.0001$ ) and A. hydrophila counts (Tukey test, $\mathrm{F}=25.63, \mathrm{p}=0.0001$ ) between the inflow, the tank and the outflow (Figure 2A-D).

In a previous study, Michaud et al. [45] frequently observed smaller counts of Pseudomonas species (35 clones and 12 isolates) isolated from water samples in a sea bass (Dicentrarchus labrax) farm. Other studies of RAS also revealed differences in the size of microbial communities colonizing biofilters and 
culture water, as well as the presence of bacterial communities characteristic of unique and complex environments $[7,18,20,58,59]$.

In our study, Ps. fluorescens and A. hydrophila counts and their percentages in total bacteria counts were lowest in water sampled at the inflow and were several to several hundred times higher in water sampled from tanks and at the outflow, regardless of the applied analytical method (Table 2, Figure 2).

Table 2. The counts of Ps. fluorescens and A. hydrophila determined by a culture-dependent method, total DAPI cell counts and the relative percentage of cells hybridized with specific probes in the water of RAS during farming of European grayling (Thymallus thymallus L.) broodstock.

\begin{tabular}{|c|c|c|c|c|c|c|}
\hline \multirow{2}{*}{ Bacteria } & \multicolumn{2}{|c|}{ Inflow ${ }^{1}$} & \multicolumn{2}{|c|}{ Tank $^{1}$} & \multicolumn{2}{|c|}{ Outflow $^{1}$} \\
\hline & Mean & Range & Mean & Range & Mean & Range \\
\hline Ps. fluorescens ${ }^{2}$ & 65 & $20-145$ & 141 & $40-250$ & 446 & $220-930$ \\
\hline A. hydrophila ${ }^{2}$ & 26 & $1-76$ & 244 & $90-342$ & 11,000 & $930-35,000$ \\
\hline Total bacterial counts 3 & 39.4 & $12.3-87.2$ & 85.6 & $42.4-202.1$ & 303.4 & $152.3-559.1$ \\
\hline EUB338 (\%) ${ }^{4}$ & 66.0 & $27.1-69.2$ & 61.7 & $16.6-69.0$ & 67.2 & $63.8-79.1$ \\
\hline GAM42a $(\%)^{4}$ & 8.2 & $6.3-18.5$ & 10.3 & $9.8-21.2$ & 15.1 & $9.4-28.6$ \\
\hline Pseudo120 (\%) 4 & 0.17 & $0.1-0.3$ & 2.6 & $1.5-3.9$ & 4.6 & $3.3-6.4$ \\
\hline KO229 (\%) ${ }^{4}$ & 0.07 & $0.05-0.10$ & 5.1 & $1.8-5.6$ & 9.9 & $7.3-11.1$ \\
\hline
\end{tabular}

1 _sampling sites, ${ }^{2}$-numbers as colony forming units $\left(\mathrm{CFU} \mathrm{mL}{ }^{-1}\right),{ }^{3}$ - total bacterial counts of $\times 10^{6}$ cells $\cdot \mathrm{mL}^{-1}$, ${ }^{4}$ - percent detection compared to DAPI (numbers have been corrected by subtracting NON338 counts).
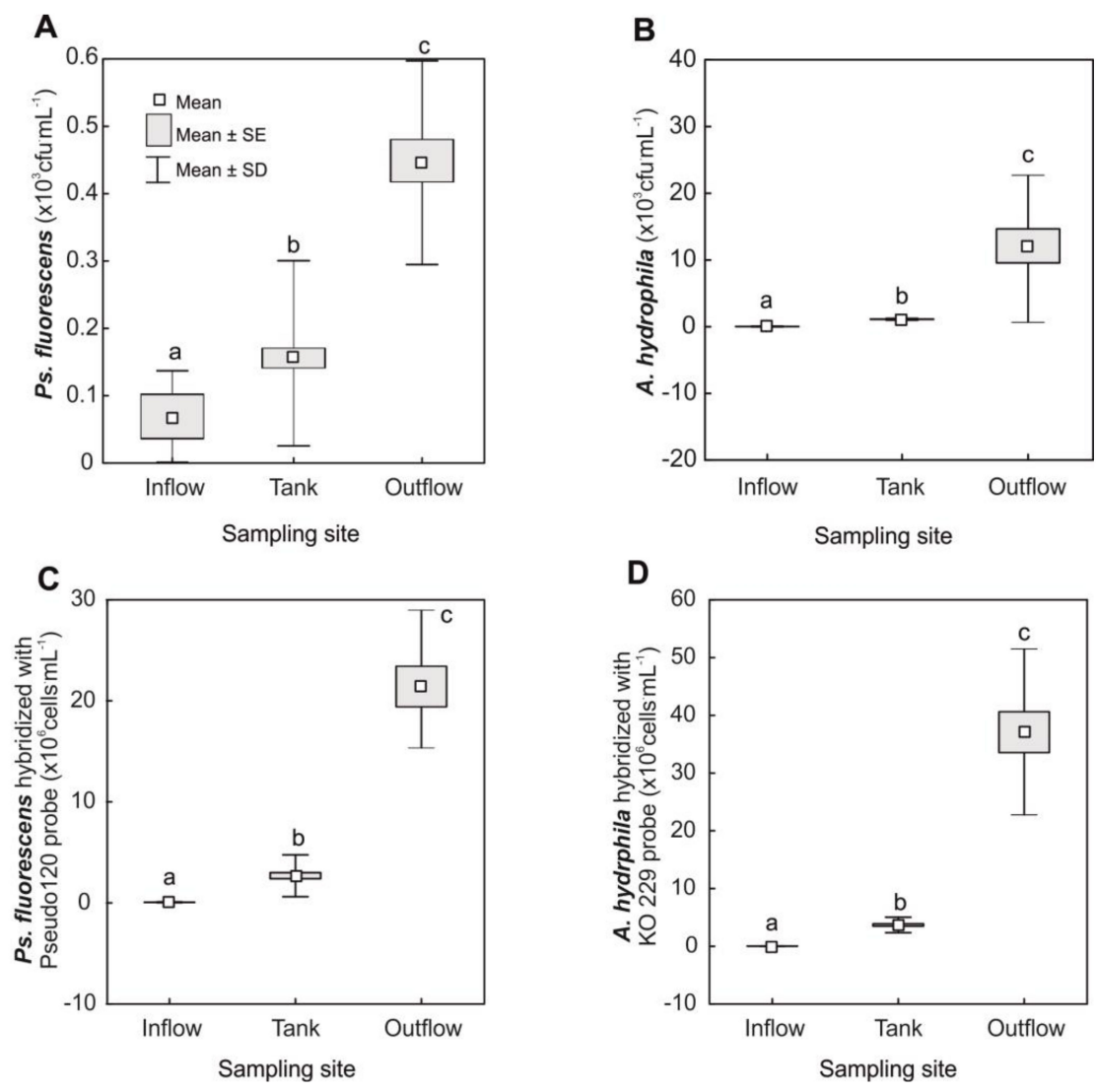

Figure 2. The counts of Pseudomonas fluorescens (A) and Aeromonas hydrophila bacteria (B) determined by a culture-dependent method and the culture-independent technique: bacteria hybridized with Pseudo120 (C) and KO 229 probes (D). The differences in the bacteria counts in water samples collected from the inflow $(\mathrm{N}=17)$, tank $(\mathrm{N}=34)$ and outflow $(\mathrm{N}=17)$ were analyzed with the Tukey multiple comparison test (RM-ANOVA, $\mathrm{p}<0.05)$. Statistically significant differences were depicted by different letters. Denotations: \pm SE—standard error, \pm SD—standard deviation.

In the FISH assay, the counts of Ps. fluorescens and A. hydrophila in inflow, tank and outflow water samples were approximately $10^{2}-10^{5}$ higher than in the culture-dependent method (Figure 2). 
It indicates that studied closed water system was more colonized by analyzed non-culturable bacteria than culturable Ps. fluorescens and A. hydrophila strains. These microbial species, which rely on organic matter (e.g., digested and undigested feed, feces, and dead fish) as a source of nutrients and energy also colonize the skin and digestive tract of fish, proliferate readily in aquatic environments such as RAS [9-13]. However, it is possible that the studied species of culturable bacteria ceased to divide and proliferate under exposure to physicochemical environmental stressors in RAS (e.g., water temperature, $\mathrm{pH}, \mathrm{OS}$, concentrations of $\mathrm{NH}_{4}-\mathrm{N}, \mathrm{NH}_{3}-\mathrm{N}$, etc.). The culturable bacteria are more sensitive on unfavorable factors in water environments. Consequently bacterial cells could be damaged and lose the ability to proliferate on standard growth media during the laboratory cultivations. Early studies $[7,8,13,60-62]$ focused on culturing techniques showed that very few bacteria species from natural populations $(<1 \%$ in water) are able to grow under standard lab conditions. Therefore we used these two methods because they allowed to analyze the total Ps. fluorescens and A. hydrophila species richness in our studies of RAS than they would have been applied separately.

In the current study, the counts of both bacterial species in water samples collected from fish rearing tanks and the outflows from fish rearing tanks increased with a rise in feed dosage and an increase in fish biomass regardless of the applied analytical method (Figure 3A,B). The greater variations in A. hydrophila counts than Ps. fluorescens counts were observed in water samples collected from both tank and outflow waters. Under aerobic conditions, microbial breakdown of organic matter leads to the production of new bacterial cells in amounts corresponding to $40-60 \%$ of metabolized organic matter [63].

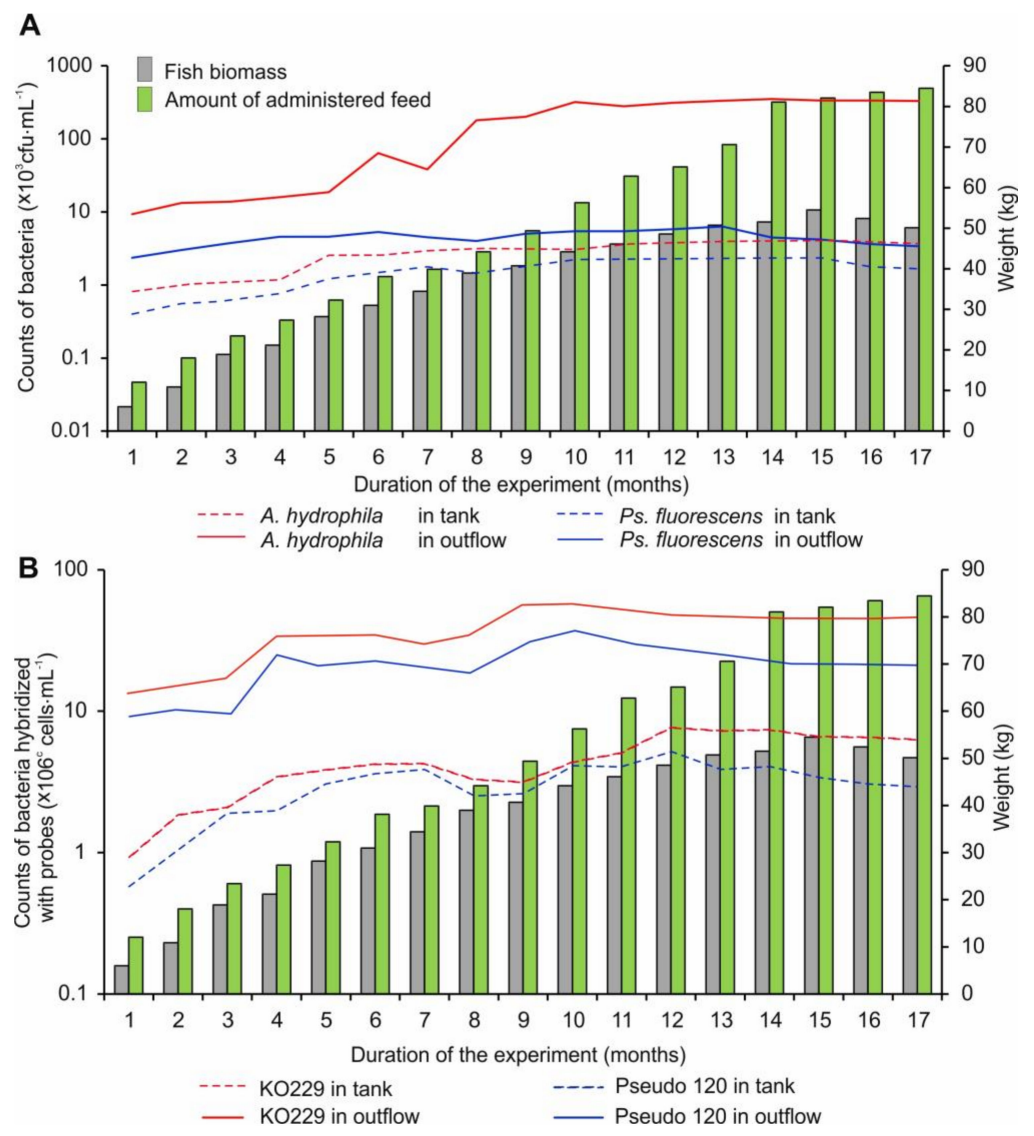

Figure 3. Changes in the counts of Pseudomonas fluorescens and Aeromonas hydrophila determined by a culture-dependent method (A) and a culture-independent method: Peudo120, KO 229 (B) in water samples collected from the fish tank and the outflow relative to cumulative fish biomass and the total amount of feed administered during the intensive rearing of European grayling (Thymallus thymallus L.) broodstock in RAS. Dashed lines represent bacterial counts in the tank, and continuous lines denote Ps. fluorescens and A. hydrophila populations at the outflow. 
In the culture-dependent method, the counts of Ps. fluorescens colonizing the feed administered to European graylings (Thymallus thymallus L.) did not exceed $5 \mathrm{cfu} \cdot \mathrm{g}^{-1}$ and these bacteria were not detected in $90 \%$ of feed samples. The presence of $A$. hydrophila was not observed in 17 feed samples determined this technique. During the experiment, the counts of Ps. fluorescens (Pseudo120) and A. hydrophila (KO 229) determined by the culture-independent method varied within a very narrow range. The abundance of $P$ s. fluorescens and A. hydrophila in the analyzed fish feed samples reached 80 to 120 cells. $\mathrm{g}^{-1}$ and 20 to 60 cells.g ${ }^{-1}$, respectively. No significant correlations between the counts of both bacterial species were observed between feed fish and water samples from the tank and the outflow $\left(\mathrm{r}_{\text {tank }}=0.200, \mathrm{r}_{\text {outfl }}=0.090\right)$.

These results suggest that the feed administered to European graylings was not a major source of Ps. fluorescens and A. hydrophila in RAS water. The results of both culture-dependent and culture-independent analyses indicate that both bacterial species were originated from autochthonous fish and water microbiota. Moreover, the administered feed contributed more to the growth of non-culturable than culturable strains of $P_{s}$. fluorescens and A. hydrophila bacteria in RAS water (Figure $3 \mathrm{~A}, \mathrm{~B})$.

During intensive fish farming, $60-80 \%$ of the administered feed is not converted into bodily tissue [64] and acts as the main source of biogenic substances and the ideal medium for the development of heterotrophic bacteria in water or bacteria which are deposited in water with fish excrement $[10,65]$. For this reason, the gut microbiota is more likely to influence the composition of bacterial communities in RAS water than feed microbiota $[1,2]$.

\subsection{Physicochemical Parameters of Water Samples}

All of the evaluated physicochemical parameters were characterized by minor fluctuations in water samples collected from the inflow, the tank and the outflow in successive months of the experiment (Table 3). The lowest values most parameters and the highest oxygen levels were noted in samples of water flowing into fish rearing tanks. The evaluated physicochemical parameters were highest in water flowing out of fish tanks. In most tank and outflow samples, an increase in $\mathrm{NH}_{4}-\mathrm{N}$, $\mathrm{NO}_{3}-\mathrm{N}, \mathrm{BOD}_{5}$, TSS, TOP, and TOC values was generally accompanied by a rise in Ps. fluorescens and $A$. hydrophila counts determined by both culture-dependent and culture-independent methods (Table 2).

According to Cytryn et al. [7] relatively high values of physicochemical parameters in water samples are indicative of a wide range of microbially-mediated transformation processes. In our study, significant differences $(\mathrm{p} \leq 0.05)$ in the values of $\mathrm{NH}_{4}-\mathrm{N}, \mathrm{BOD}_{5}, \mathrm{TSS}, \mathrm{TOP}$, and TOC were observed between sampling sites (Table 3). The physicochemical parameters of all water samples were within the limits recommended by the Global Aquaculture Alliance [66]. In line with the above guidelines, water parameters should be kept within the following limits to optimize fish culturing conditions in aquacultures and to minimize their adverse effects on the natural environment: $\mathrm{pH}$ of 6 to 9 , TSS $\leq 50 \mathrm{mg} \cdot \mathrm{L}^{-1}, \mathrm{TP} \leq 0.3 \mathrm{mg} \cdot \mathrm{L}^{-1}, \mathrm{NH}_{3}-\mathrm{N} \leq 3.0, \mathrm{BOD}_{5} \leq 30 \mathrm{mg} \cdot \mathrm{L}^{-1}$ and $\mathrm{DO} \geq 5.0 \mathrm{mg} \cdot \mathrm{L}^{-1}$. 
Table 3. Mean values and standard deviation $( \pm S D)$ of the physicochemical parameters of water samples collected from the inflow to fish tanks, from fish tanks and from the outflow from tanks in RAS during farming of European grayling (Thymallus thymallus L.) broodstock. Statistically significant differences between water samples collected from the inflow $(\mathrm{N}=17)$, tank $(\mathrm{N}=34)$ and outflow $(\mathrm{N}=17)$ were assessed by the Tukey multiple comparison test (RM-ANOVA, $\mathrm{p} \leq 0.05)$ and depicted by different letters: $a$-inflow and $b$-tank. Dissolved oxygen (DO), oxygen saturation (OS), 5-day biochemical oxygen demand $\left(\mathrm{BOD}_{5}\right)$, orthophosphates $\left(\mathrm{PO}_{4}-\mathrm{P}\right)$, total phosphorus $(\mathrm{TP}), \mathrm{NH}_{4}-\mathrm{N}, \mathrm{NH}_{3}-\mathrm{N}$, $\mathrm{NO}_{2}-\mathrm{N}, \mathrm{NO}_{3}-\mathrm{N}$, total suspended solids (TSS), total organic carbon (TOC), total nitrogen (TN), total organic nitrogen (TON), and total organic phosphorus (TOP).

\begin{tabular}{|c|c|c|c|}
\hline \multirow{2}{*}{ Parameter (Unit) } & \multicolumn{3}{|c|}{ Sampling Sites } \\
\hline & Inflow & Tank & Outflow \\
\hline $\mathrm{T}\left({ }^{\circ} \mathrm{C}\right)$ & $10.0 \pm 2.5$ & $10.6 \pm 2.4$ & $10.6 \pm 2.3$ \\
\hline $\mathrm{DO}\left(\mathrm{mg} \cdot \mathrm{L}^{-1}\right)$ & $10.03 \pm 0.53$ & $9.9 \pm 0.6$ & $9.01 \pm 0.61$ \\
\hline $\mathrm{OS}\left(\% \mathrm{O}_{2}\right)$ & $90.9 \pm 3.7$ & $84.6 \pm 21.4$ & $80.1 \pm 3.2$ \\
\hline $\mathrm{pH}$ & $7.9 \pm 0.14$ & $8.0 \pm 0.15$ & $8.20 \pm 0.15$ \\
\hline $\mathrm{PO}_{4}-\mathrm{P}\left(\mathrm{mg} \mathrm{P} \cdot \mathrm{L}^{-1}\right)$ & $0.545 \pm 0.152$ & $0.554 \pm 0.161$ & $0.596 \pm 0.121$ \\
\hline TOP $\left(\mathrm{mg} \mathrm{P} \cdot \mathrm{L}^{-1}\right)$ & $0.164 \pm 0.051 \mathrm{a}$ & $0.233 \pm 0.059 b$ & $0.281 \pm 0.064 b$ \\
\hline $\mathrm{TP}\left(\mathrm{mg} \mathrm{P} \cdot \mathrm{L}^{-1}\right)$ & $0.710 \pm 0.164$ & $0.784 \pm 0.188$ & $0.910 \pm 0.191$ \\
\hline $\mathrm{NH}_{4}-\mathrm{N}\left(\mathrm{mg} \mathrm{N} \cdot \mathrm{L}^{-1}\right)$ & $0.038 \pm 0.017$ & $0.065 \pm 0026$ & $0.075 \pm 0.070$ \\
\hline $\mathrm{NH}_{3}-\mathrm{N}\left(\mathrm{mg} \mathrm{N} \cdot \mathrm{L}^{-1}\right)$ & $0.002 \pm 0.001$ & $0.003 \pm 0.001$ & $0.003 \pm 0.001$ \\
\hline $\mathrm{NO}_{2}-\mathrm{N}\left(\mathrm{mg} \mathrm{N} \cdot \mathrm{L}^{-1}\right)$ & $0.004 \pm 0.003$ & $0.018 \pm 0.009$ & $0.011 \pm 0.001$ \\
\hline $\mathrm{NO}_{3}-\mathrm{N}\left(\mathrm{mg} \mathrm{N} \cdot \mathrm{L}^{-1}\right)$ & $8.848 \pm 2.385$ & $8.455 \pm 2.727$ & $8.152 \pm 2.837$ \\
\hline TON $\left(\mathrm{mg} \mathrm{N} \cdot \mathrm{L}^{-1}\right)$ & $3.041 \pm 1.147$ & $4.576 \pm 1.203$ & $4.733 \pm 1.282$ \\
\hline $\mathrm{TN}\left(\mathrm{mg} \mathrm{N} \cdot \mathrm{L}^{-1}\right)$ & $11.83 \pm 2.93$ & $13.10 \pm 2.95$ & $13.17 \pm 2.95$ \\
\hline $\mathrm{BOD}_{5}\left(\mathrm{mg} \mathrm{O}_{2} \cdot \mathrm{L}^{-1}\right)$ & $1.95 \pm 0.47 a$ & $2.64 \pm 0.57 b$ & $3.82 \pm 0.67 \mathrm{~b}$ \\
\hline TSS $\left(\mathrm{mg} \cdot \mathrm{L}^{-1}\right)$ & $1.94 \pm 0.78 \mathrm{a}$ & $4.29 \pm 1.69 b$ & $4.86 \pm 2.02 b$ \\
\hline TOC $\left(\mathrm{mg} \mathrm{C} \cdot \mathrm{L}^{-1}\right)$ & $3.01 \pm 0.33 a$ & $4.31 \pm 0.62 b$ & $4.45 \pm 0.71 b$ \\
\hline
\end{tabular}

\subsection{Relationships between Bacterial Counts and Environmental Variables}

The RDA demonstrated that 6 out of 18 environmental factors markedly affected the total counts of Ps. fluorescens and A. hydrophila in the RAS, determined by culture-dependent and culture-independent methods (Figure 4). Regardless of the sampling site (inflow, tank or outflow), the two main factors (axes) explained $70.35 \%$ of total variance. After forward selection of environmental variables, the RDA model generated the following significant variables $\left(\lambda_{A}\right)$ at $p \leq 0.05$ : feed amount $\left(\lambda_{A}=0.018\right)$, fish biomass $\left(\lambda_{A}=0.018\right)$, TSS $\left(\lambda_{A}=0.018\right)$, TOP $\left(\lambda_{A}=0.018\right), \operatorname{BOD}_{5}\left(\lambda_{A}=0.018\right)$ and TOC $\left(\lambda_{A}=0.036\right)$. After the Bonferroni correction, the first axis explained $68.5 \%$ of the variance, and the second axis explained $1.6 \%$ of the variance (70.35\% of total variance) in the abundance of Ps. fluorescens and A. hydrophila determined by culture-dependent and culture independent methods, and all the canonical axes were significant (Monte Carlo test, $\mathrm{p}=0.002$ ). The first factor was very strongly linked with the amount of feed $\left(\lambda_{A}=0.500\right)$, fish biomass $\left(\lambda_{A}=0.016\right)$, TSS $\left(\lambda_{A}=0.064\right)$ and TOC $\left(\lambda_{A}=0.032\right)$, which explained $56.3 \%$ of total variance. In the RDA model, the strongest positive relationships were noted between Ps. fluorescens (Pseudo120) and A. hydrophila (KO229) counts determined by the culture-independent method vs. the amount of feed and total organic carbon (TOC) concentration. In contrast, fish biomass, TSS and $\mathrm{BOD}_{5}$ were most closely correlated with Ps. fluorescens and A. hydrophila counts determined by the culture-dependent method. 


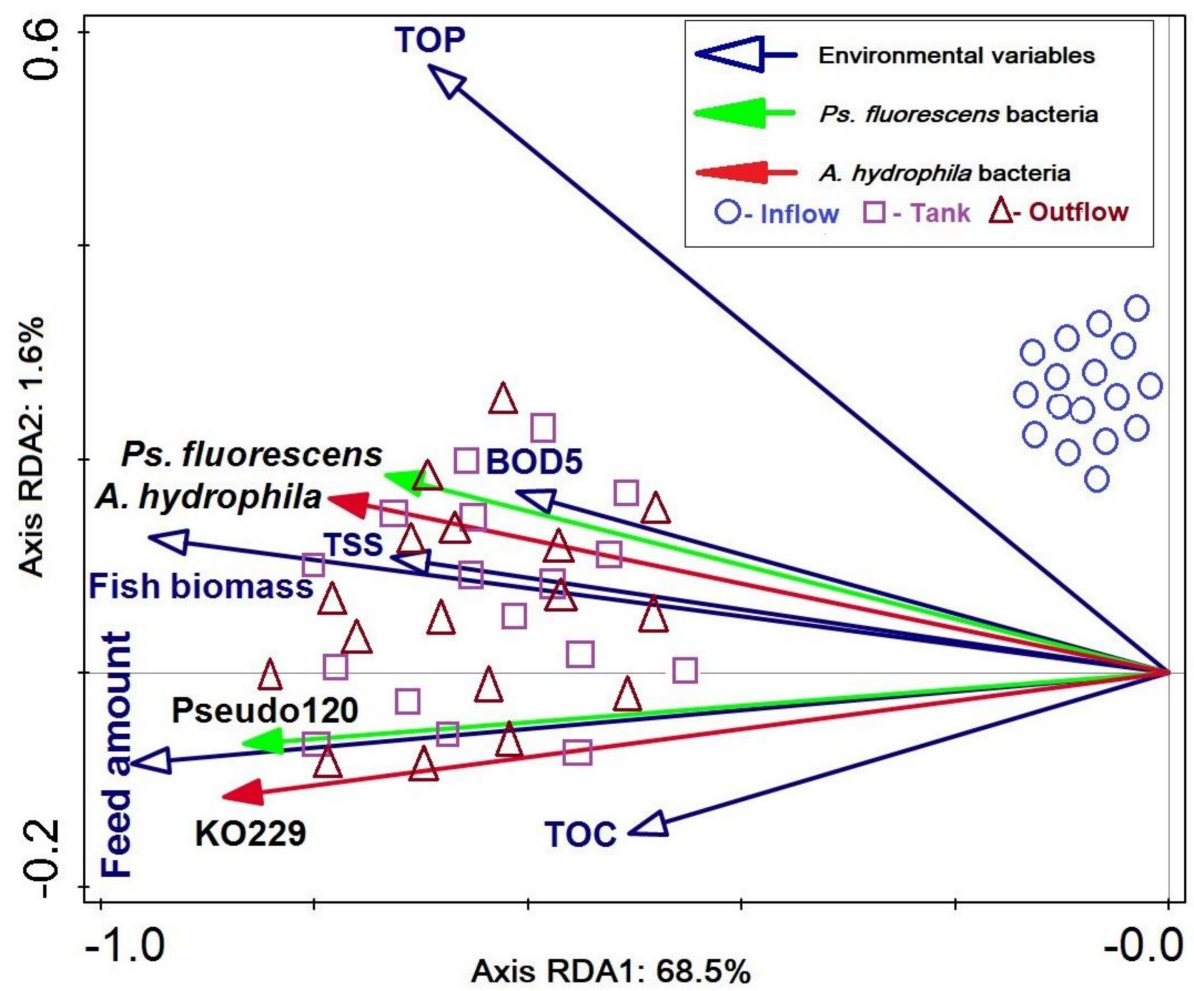

Figure 4. Redundancy analysis (RDA) biplot of the correlations $(\mathrm{p} \leq 0.05)$ between Pseudomonas fluorescens and Aeromonas hydrophila counts and environmental variables determined by culture-dependent and culture-independent methods (Peudo120, KO 229) in samples of RAS water during intensive rearing of European grayling (Thymallus thymallus L.) broodstock.

The results of this study are consistent with the findings of other authors $[2,7,8]$ who reported significant correlations $(\mathrm{p} \leq 0.05)$ between the physiochemical parameters of water $\left(\mathrm{pH}\right.$, conductivity, $\left.\mathrm{PO}_{4}-\mathrm{P}, \mathrm{NO}_{3}-\mathrm{N}\right)$ versus the diversity and distribution of bacteria in horizontal and vertical profiles in experiments performed in Nile tilapia larvae [2], a marine culture system [7], and a rainbow trout farm [8].

In our study, the positive correlations between Ps. fluorescens and A. hydrophila counts determined by culture-dependent and culture-independent methods versus the amount administered feed, fish biomass, and $\mathrm{BOD}_{5}, \mathrm{TSS}$, and TOC concentrations indicate that some factors were influenced mainly by the size of Ps. fluorescens and A. hydrophila populations in the analyzed RAS. The studied bacterial species are capable of metabolising nitrogen and carbon from various sources, and they proliferate most rapidly in the presence of readily oxidizable organic matter from fish feed which is utilized with $80-90 \%$ efficiency $[18,67]$. These results indicate that intensively farmed European graylings increase the abundance of culturable and non-culturable potentially pathogenic Ps. fluorescens and A. hydrophila in RAS.

\section{Conclusions}

The counts of Ps. fluorescens and A. hydrophila bacteria determined with the use of culturedependent and culture-independent methods had mainly relationships with the amount of feed administered to European graylings (Thymallus thymallus L.), fish biomass and increasing water pollution ( $\mathrm{BOD}_{5}, \mathrm{TSS}$, and TOC concentrations) in the RAS. Significant differences in the counts of Ps. fluorescens and A. hydrophila between sampling sites, and the fact that they were strongly correlated with feed dose and total fish biomass, indicate that these farming conditions and the nutrient requirements of European graylings affect the abundance of the analyzed potentially pathogenic bacteria. Ps. fluorescens and A. hydrophila constitute natural microbiota of water environments and aquatic organisms, but an increase in their populations and activity under exposure to environmental 
stressors and pollution can induce adverse changes in biotopes and pose a risk for microorganisms, animals and humans.

The administration of commercial fish feed significantly increased the populations of all bacterial groups in water samples collected directly from fish rearing tanks and from water flowing out of fish tanks relative to purified water flowing into fish tanks. The counts of Ps. fluorescens and A. hydrophila bacteria in a European grayling (Thymallus thymallus L.) farm were significantly higher in analyses conducted with the use of a culture-independent method than a culture-dependent method. The acquired data support reliable evaluations of bacterial contamination in RAS water, which is an important consideration in ensuring microbiological safety, maintaining fish welfare and monitoring the farming process. The results of this study indicate that culture-dependent and culture-independent methods should be applied simultaneously to evaluate the bacteriological stability of aquacultures to minimize the risk of underestimating microbiological contamination levels. These findings can be used to control the growth of potentially pathogenic bacterial species and their transfer between natural environments and aquatic organisms. Our results are particularly valuable for aquacultures that help to replenish wild stocks and rebuild populations of threatened species in natural aquatic environments, which was the case in the present experiment. Potentially pathogenic microorganisms, such as Ps. fluorescens and A. hydrophila, can spread from aquacultures and contaminate the natural environment with non-specific microbiota. These bacteria are evacuated from various aquaculture systems in high concentrations in water. Furthermore, most of them can be potentially pathogenic for fish and humans as they are characterized by high levels of cross-resistance to different antibiotics. These allochthonous microorganisms can lead to changes in the populations of autochthonous bacteria in aquatic ecosystems and disrupt natural processes induced by indigenous microbial communities.

Author Contributions: Conceptualization, I.G. and M.S.; Data curation, I.G., M.S., J.P., M.Ł., A.G.-P. and K.G.-L.; Formal analysis, I.G., M.S., J.P., M.Ł. and A.G.-P.; Investigation, I.G., M.S., J.P. and A.G.-P.; Methodology, I.G., M.S., M.Ł. and A.G.-P.; Resources, M.S.; Software, I.G.; Supervision, I.G.; Visualization, M.Ł.; Writing一original draft, I.G., M.S., K.G.-L.; Writing—review and editing, I.G., K.G.-L.

Funding: This research received no external funding.

Acknowledgments: This study was supported by research grants No. 18.610-004-300 and No. 18.610.001-300 from the Ministry of Science and Higher Education (Poland).

Conflicts of Interest: The authors declare that they have no conflict of interest.

\section{References}

1. Bakke, I.; Skjermo, J.; Vo, T.A.; Vadstein, O. Live feed is not a major determinant of the microbiota associated with cod larvae (Gadus morhua). Environ. Microbiol. Rep. 2013, 5, 537-548. [CrossRef] [PubMed]

2. Giatsis, C.; Sipkema, D.; Smidt, H.; Heilig, H.; Benvenuti, G.; Verreth, J.; Verdegem, M. The impact of rearing environment on the development of gut microbiota in tilapia larvae. Sci. Rep. 2015, 5, 18206. [CrossRef] [PubMed]

3. Terech-Majewska, E.; Pajdak, J.; Siwicki, A.K. Water as a source of macronutrients and micronutrients for fish, with special emphasis on the nutritional requirements of two fish species: The common carp (Cyprinus carpio) and the rainbow trout (Oncorhynchus mykiss). J. Elem. 2016, 21, 947-961.

4. Harnisz, M.; Gołaś, I.; Pietruk, M. Tetracycline-resistant bacteria as indicators of antimicrobial resistance in protected waters-The example of the Drwęca River nature reserve (Poland). Ecol. Indic. 2011, 11, $663-668$. [CrossRef]

5. Harnisz, M.; Korzeniewska, E.; Gołaś, I. The impact of a freshwater fish farm on the community of tetracycline-resistant bacteria and the structure of tetracycline resistance genes in river water. Chemosphere 2015, 128, 134-141. [CrossRef] [PubMed]

6. Terech-Majewska, E. Improving disease prevention and treatment in controlled fish culture. Arch. Pol. Fish. 2016, 24, 115-165. [CrossRef] 
7. Cytryn, E.; Gelfand, I.; Barak, Y.; van Rijn, J.; Minz, D. Diversity of microbial communities correlated to physiochemical parameters in a digestion basin of a zero-discharge mariculture system. Environ. Microbiol. 2003, 5, 55-63. [CrossRef] [PubMed]

8. Auffret, M.; Yergeau, E.; Pilote, A.; Proulx, E.; Proulx, D.; Greer, C.W.; Vandenberg, G.; Villemur, R. Impact of water quality on the bacterial populations and off-flavours in recirculating aquaculture systems. FEMS Microbiol. Ecol. 2013, 84, 235-247. [CrossRef] [PubMed]

9. Blancheton, J.P.; Attramadal, K.J.K.; Michaud, L.; Roque d'Orbcastel, E.; Vadstein, O. Insight into bacterial population in aquaculture systems and its implication. Aquacult. Eng. 2013, 53, 30-39. [CrossRef]

10. Gołaś, I.; Zmysłowska, I.; Harnisz, M.; Teodorowicz, M. The microbiological state of fish feed, water and Silurus glanis L. skin of fry during intensive rearing. Bull. Sea Fish. Inst. 2004, 1, 3-14.

11. Krause, J.; Zmysłowska, I.; Gołaś, I. Potentially pathogenic bacteria in water and Siberian sturgeon (Acipenser baeri Br.) with Russian sturgeon (Acipenser gueldenstaedti Br.) hybrids in a closed water cycle. Bull. Sea Fish. Inst. 2005, 3, 65-77.

12. Krause, J.; Zmysłowska, I.; Gołaś, I.; Szarek, J. Qualitative composition of bacterial microflora of tank water and hybrid of Siberian sturgeon (Acipenser baeri Br.) with Russian sturgeon (Acipenser gueldenstaedti Br.) from intensive rearing in a closed water system. Pol. J. Natur. Sci. 2006, 20, 345-354.

13. Sugita, H.; Nakamura, H.; Shimada, T. Microbial communities associated with filter material in recirculating aquaculture systems of freshwater fish. Aquaculture 2005, 243, 403-409. [CrossRef]

14. Kawahara, N.; Shigematsu, K.; Miyadai, T.; Kondo, R. Comparison of bacterial communities in fish farm sediments along organic enrichment gradient. Aquaculture 2009, 287, 107-113. [CrossRef]

15. Bacelar-Nicolau, P.; Nicolau, L.B.; Marques, J.C.; Morgado, F.; Pastorinho, R.; Azeiteiro, U.M. Bacterioplankton dynamics in the Mondego eustary (Portugal). Acta Oecol. 2003, 24, S67-S75. [CrossRef]

16. Thayumanavan, T.; Vivekanandhan, G.; Savithamani, K.; Subashkumar, R.; Lakshmanaperumalsamy, P. Incidence of haemolysin-positive and drug-resistant Aeromonas hydrophila in freshly caught fin fish and prawn collected from major commercial fishes of coastal South India. FEMS Immunol. Med. Mic. 2003, 36, 41-45. [CrossRef]

17. Zhou, Q.L.; Li, K.; Jun, X.; Bo, L. Role and functions of beneficial microorganisms in sustainable aquaculture. Bioresour. Technol. 2009, 100, 3780-3786. [CrossRef] [PubMed]

18. Roca, C.; Olsson, L. Dynamic responses of Pseudomonas fluorescens DF57 to nitrogen or carbon source addition. J. Biotechnol. 2001, 86, 39-50. [CrossRef]

19. Saha, R.S.; Donofrio, D.; Goeres, M.; Bagley, S.T. Rapid detection of rRNA group I pseudomonads in contaminated metalworking fluids and biofilm formation by fluorescent in situ hybridization. Appl. Microbiol. Biotechnol. 2012, 94, 799-808. [CrossRef] [PubMed]

20. Pianetti, A.; Battistelli, M.; Citterio, B.; Parlani, C.; Falcieri, E.; Bruscolini, F. Morphological changes of Aeromonas hydrophila in response to osmotic stress. Micron 2009, 40, 426-433. [CrossRef] [PubMed]

21. Picot, L.; Abdelmoula, S.M.; Mérieau, A.; Orange, N.; Feuilloley, M.G.J. The psychotropic bacterium Pseudomonas fluorescens can adapt to human physiologic temperature and behaves as a pathogen in central and peripheral nerve cells. Eur. J. Cell Biol. 2000, 52, 129-132.

22. Picot, L.; Abdelmoula, S.M.; Merieau, A.; Leroux, P.; Cazin, L.; Orange, N.; Feuilloley, M.G.J. Pseudomonas fluorescens as a potential pathogen: Adherence to nerve cells. Microbes Infect. 2001, 3, 985-995. [CrossRef]

23. Shayo, S.D.; Mwita, C.J.; Hosea, K.M. Virulence of Pseudomonas and Aeromonas bacteria recovered from Oreochromis niloticus (Perege) from Mtera hydropower Dam; Tanzania. Ann. Biol. Res. 2012, 3, 5157-5161.

24. Holmes, P.; Sartory, D.P. An evaluation of media for the membrane filtration enumeration of Aeromonas from drinking water. Lett. Appl. Microbiol. 1993, 17, 58-60. [CrossRef]

25. Johnsen, K.; Nielsen, P. Diversity of Pseudomonas strains isolated with King's B and Gould's S1 agar determined by repetitive extragenic palindromic-polymerase chain reaction, 16S rDNA sequencing and Fourier transform infrared spectroscopy characterisation. FEMS Microbiol. Lett. 1999, 173, 155-162. [CrossRef] [PubMed]

26. Amann, R.; Snaidr, J.; Wagner, M.; Ludwig, W.; Schleifer, K.H. In situ visualization of high genetic diversity in a natural microbial community. J. Bacteriol. 1996, 178, 3496-3500. [CrossRef] [PubMed]

27. Franke-Whittle, I.; Klammer, S.; Insam, H. Design and application of an oligonucleotide microarray for the investigation of compost microbial communities. J. Microbiol. Methods 2005, 62, 37-56. [CrossRef] [PubMed] 
28. Gotkowska-Płachta, A.; Gołaś, I.; Korzeniewska, E.; Koc, J.; Rochwerger, A.; Solarski, K. Evaluation of the distribution of faecal indicator bacteria in a river system depending on different types of land use in the southern watershed of the Baltic Sea. ESPR 2016, 23, 4073-4085. [CrossRef] [PubMed]

29. Ringø, E.; Olsen, R.E. The effect of diet on aerobic bacterial flora associated with intestine of Arctic charr (Salvelinus alpinus L.). J. Appl. Microbiol. 1999, 86, 22-28. [CrossRef] [PubMed]

30. Tamaki, H.; Sekiguchi, Y.; Hanada, S.; Nakamura, K.; Nomura, N.; Matsumura, M.; Kamagata, Y. Comparative analysis of bacterial diversity in freshwater sediment of a shallow eutrophic lake by molecular and improved cultivation-based techniques. Appl. Environ. Microbiol. 2005, 71, 2162-2169. [CrossRef] [PubMed]

31. Mallet, J.P.; Lamouroux, N.; Sagnes, P.; Persat, H. Habitat preferences of European grayling in a medium size stream, the Ain river, France. J. Fish Biol. 2000, 56, 1312-1326. [CrossRef]

32. Ovidio, M.; Philippart, J.C. The impact of small physical obstacles on upstream movements of six species of fish. Hydrobiologia 2002, 483, 55-69. [CrossRef]

33. Penczak, T.; Kruk, A. Threatened obligatory riverine fishes in human-modified Polish rivers. Ecol. Freshwater Fish 2000, 9, 109-117. [CrossRef]

34. Wiśniewolski, W. Factors supporting and preventing the development and maintenance of fish populations in flowing waters. Suppl. Acta Hydrobiol. 2002, 3, 1-28.

35. Augustyn, L.; Nowak, M. Assessment of populations of European grayling, Thymallus thymallus (L.) in the Dunajec River catchment based on recreational catch records. Kom. Ryb. 2014, 4, 9-15.

36. Fjeld, E.; Haugen, T.O.; Vøllestad, L.A. Permanent impairment in the feeding behavior of grayling (Thymallus thymallus) exposed to methylmercury during embryogenesis. Sci. Total Environ. 1998, 213, 247-254. [CrossRef]

37. Honkanen, J.O.; Kostamo, A.; Kukkonen, J.V.K. Toxicity of a phytosterol mixture to grayling (Thymallus thymallus) during early developmental stages. Arch. Environ. Contam. Toxicol. 2005, 48, 391-396. [CrossRef] [PubMed]

38. Vuorinen, P.J.; Peuranen, S.; Tigerstedt, C. Effects of iron, aluminium, dissolved humic material and acidity of grayling (Thymallus thymallus) in laboratory exposures, and a comparison of sensitivity with brown trout (Salmo trutta). Boreal Environ. Res. 1998, 3, 405-419.

39. Horka, P.; Ibbotson, A.; Jones, J.I.; Cove, R.J.; Scott, L.J. Validation of scale-age determination in European grayling Thymallus thymallus using tag-recapture analysis. J. Fish Biol. 2010, 77, 153-161. [CrossRef] [PubMed]

40. Witkowski, A.; Błachuta, J.; Kokurewicz, B.; Kowalewski, M. Changes of gonadosomatic index (GSI) and egg diameter in the Thymallus thymallus (L.) in annual cycle. Acta Ichtyol. Pisc. 1989, 19, 21-28. [CrossRef]

41. Witkowski, A.; Kotusz, J.; Przybylski, M. The degree of threat to the freshwater ichthyofauna of Poland: 2009 Red List of Fish and Lamprey Species. Chrońmy Przyr. Ojcz. 2009, 65, 33-52. (In Polish)

42. Szmyt, M.; Niewiadomski, P. Evaluation of European grayling (Thymallus thymallus L.) farming in recirculating systems in view of active protection measures. In Proceedings of the 24th National Symposium on Comprehensive Research and Protection of the Natural Environment, Tlen, Poland, 26-27 June 2017; 2017; pp. 237-249. (In Polish)

43. Szmyt, M.; Lejk, A.M.; Ciereszko, A.; Woźniak, M.; Dietrich, G.J.; Judycka, S.; Roszuk, J.; Polewacz, A.; Lampkowski, M.; Pasturczak, F.; et al. Broodstock selection and an evaluation of controlled reproduction in the European grayling (Thymallus thymallus L.) in a recirculating aquaculture system (RAS). In Proceedings of the 60th Conference of Salmonid Breeders, Gdynia, Poland, 8-9 October 2015.

44. Gołaś, I.; Korzekwa, K.; Harnisz, M.; Zmysłowska, I.; Teodorowicz, M.; Terech-Majewska, E.; Rodziewicz, W.; Bieńkowska, M. Influence of fishery management and environmental factors on occurrence of heterotrophic, hemolytic and mesophilic bacteria and Aeromonas hydrophila in waters of Drwęca River, Poland. Arch. Environ. Prot. 2009, 35, 27-40.

45. Michaud, L.; Lo Giudice, A.; Troussellier, M.; Smedile, F.; Bruni, V.; Blancheton, J.P. Phylogenetic characterization of the heterotrophic bacterial communities inhabiting a marine recirculating aquaculture system. J. Appl. Microbiol. 2009, 107, 1935-1946. [CrossRef] [PubMed]

46. APHA. Standard Methods for the Examination of Water and Wastewater, 15th ed.; Water Pollution Control Federation: New York, NY, USA, 1992.

47. Loy, A.; Maixner, F.; Wagner, M.; Horn, M. ProbeBase-An online resource for rRNA-targeted oligonucleotide probes: New features 2007. Nucleic Acids Res. 2007, 3, 800-804. [CrossRef] [PubMed] 
48. Pernthaler, J.F.; Glöckner, O.; Schönhuber, W.; Amann, R. Fluorescence in situ hybridization with rRNA-targeted oligonucleotide probes. In Fluorescence In Situ Hybridization, Methods in Microbiology: Marine Microbiology; Pernthaler, J.F., Glöckner, O., Schönhuber, W., Amann, R., Paul, J., Eds.; Academic Press Ltd.: London, UK, 2001; Volume 30, pp. 207-226.

49. Manz, W.; Amann, R.; Ludwig, W.; Wagner, M.; Schleifer, K.H. Phylogenetic oligodeoxynucleotide probes for the major subclasses of Proteobacteria: Problems and solutions. Syst. Appl. Microbiol. 1992, 15, 593-600. [CrossRef]

50. Daims, H.; Brühl, A.; Amann, R.; Schleifer, K.H.; Wagner, M. The domain-specific probe EUB338 is insufficient for the detection of all Bacteria: Development and evaluation of a more comprehensive probe set. Syst. Appl. Microbiol. 1999, 22, 434-444. [CrossRef]

51. Amann, R.I.; Binder, B.J.; Olson, R.J.; Chisholm, S.W.; Devereux, R.; Stahl, D.A. Combination of 16SrRNA-targeted oligonucleotide probes with flow cytometry for analyzing mixed microbial populations. Appl. Environ. Microbiol. 1990, 56, 1919-1925. [PubMed]

52. Wallner, G.; Amann, R.; Beisker, W. Optimizing fluorescent in situ hybridization with rRNA-targeted oligonucleotide probes for flow cytometric identification of microorganisms. Cytometry 1993, 14, 136-143. [CrossRef] [PubMed]

53. Brosius, J.; Dull, T.J.; Sleeter, D.D.; Noller, H.F. Gene organization and primary structure of a ribosomal RNA operon from Escherichia coli. J. Mol. Biol. 1981, 148, 107-127. [CrossRef]

54. Quinn, G.P.; Keough, M.J. Experimental Design and Data Analysis for Biologists; Cambridge University Press: New York, NY, USA, 2002.

55. Ter Braak, C.J.F.; Šmilauer, P. CANOCO Reference Manual and Canodraw for Windows User's Guide, Software for Canonical Community Ordination, version 4.5; Microcomputer Power: Ithaca, NY, USA, 2002; p. 500.

56. Lepš, J.; Šmilauer, P. Multivariate Analysis of Ecological Data Using Canoco; Cambridge University Press: Cambridge, UK, 2003; p. 269.

57. Ter Braak, C.J.F.; Šmilauer, P. Canoco Reference Manual and User's Guide: Software for Ordination, version 5.0; Microcomputer Power: Ithaca, NY, USA, 2012; 496p.

58. Leonard, N.; Blancheton, J.P.; Guiraud, J.P. Populations of heterotrophic bacteria in an experimental recirculating aquaculture system. Aquacult. Eng. 2000, 22, 109-120. [CrossRef]

59. Wietz, M.; Hall, M.R.; Hoj, L. Effects of seawater ozonation on biofilm development in aquaculture tanks. Syst. Appl. Microbiol. 2009, 32, 266-277. [CrossRef] [PubMed]

60. Matos, A.; Borges, M.-T.; Peixe, C.; Henriques, I.; Pereira, C.M.; Castro, P.M.L. A molecular and multivariate approach to the microbial community of a commercial shallow raceway marine recirculation system operating with a moving bed biofilter. Aquac. Res. 2011, 42, 1308-1322. [CrossRef]

61. Keller, M.; Zengler, K. Tapping into microbial diversity. Nat. Rev. Microbiol. 2004, 2, 141-150. [CrossRef] [PubMed]

62. Kisand, V.; Wikner, J. Combining culture dependent and -independent methodologies for estimation of richness of estuarine bacterioplankton consuming riverine dissolved organic matter. Appl. Environ. Microbiol. 2003, 69, 3607-3616. [CrossRef] [PubMed]

63. Avnimelech, Y. Carbon and nitrogen ratio as a control element in aquaculture systems. Aquaculture 1999, 176, 227-235. [CrossRef]

64. Beveridge, M.C.M.; Philips, M.J.; Macintosh, D.C. Aquaculture and environment: The supply and demand for environment goods and services by Asian aquaculture and the implications for sustainability. Aquac. Res. 1997, 28, 101-111. [CrossRef]

65. Sidoruk, M.; Cymes, I. Effect of water management technology used in trout culture on water quality in fish ponds. Water 2018, 10, 1264. [CrossRef]

66. Boyd, C.E. Guidelines for aquaculture effluent management at the farm-level. Aquaculture 2003, 226, 101-112. [CrossRef]

67. Michaud, L.; Blancheton, J.P.; Bruni, V.; Piedrahita, R. Effect of particulate organic carbon on heterotrophic bacterial populations and nitrification efficiency in biological filters. Aquacult. Eng. 2006, 34, 224-233. [CrossRef]

(C) 2019 by the authors. Licensee MDPI, Basel, Switzerland. This article is an open access article distributed under the terms and conditions of the Creative Commons Attribution (CC BY) license (http://creativecommons.org/licenses/by/4.0/). 